\title{
Effects of Preoperative Anxiety and General Anesthetic Administration on Intraoperative Awareness in Patients Undergoing Cesarean Section
}

\author{
Gebelerde Preoperatif Anksiyetenin ve Genel Anestezi Uygulamalarının \\ intraoperatif Farkındalık Üzerine Etkisi
}

\author{
๑ Nilay Nur Gençoğlu, ๑ Gamze Küçükosman, ๑ Bengü Gülhan Aydın, ๑ Dilek Rahşan Okyay, \\ ๑ Özcan Pişkin, ๑ Üstün Sezer, • Mehmet İbrahim Harma*, • Hilal Ayoğlu
}

Bülent Ecevit University Faculty of Medicine, Department of Anesthesiology and Reanimation, Zonguldak, Turkey

*Bülent Ecevit University Faculty of Medicine, Department of Obstetrics and Gynecology, Zonguldak, Turkey

Abstract

Aim: The aim was to investigate the effects of preoperative anxiety and general anesthetic administrations on intraoperative awareness among patients undergoing cesarean section.

Methods: This prospective randomized study included 90 pregnant subjects. Preoperative anxiety was assessed using the Beck Anxiety Inventory. The patients were divided into three groups: group $P$ received propofol $2.5 \mathrm{mg} / \mathrm{kg}$, group T thiopental $5 \mathrm{mg} / \mathrm{kg}$ and group $\mathrm{K}$ received ketamine $1 \mathrm{mg} / \mathrm{kg}$. Data on intraoperative hemodynamics, isolated forearm (IFA) responses and time to first pain and to first analgesic requirement evaluated using postoperative numerical rating scale were recorded. The Modified Brice Scale (MBS) was used to assess awareness.

Results: The preoperative anxiety levels in the groups were low and demographic data were similar ( $p>0.05$ ). There was no statistically significant difference in IFA response between the groups $(p>0.05)$. Group T had higher MAP at all times and NRS values at hour 0 compared to the other groups $(p<0.05)$, and had shorter time to first analgesic requirement $(p<0.05)$. MBS responses were evaluated as recall in 12 cases in group $\mathrm{K}$, four in group $\mathrm{P}$ and three in group $\mathrm{T}$.

Conclusion: As the anxiety levels in pregnants were low, the superiority of agents used in induction over each other regarding awareness could not be shown.

Keywords: Anxiety, bispectral index, cesarean section, end-tidal sevoflurane, awareness, isolated forearm
Öz

Amaç: Sezaryen seksiyo olgularında, preoperatif anksiyetenin ve genel anestezi uygulamalarının intraoperatif farkındalık üzerine etkilerinin araştırılması amaçlanmıştır.

Yöntemler: Prospektif, randomize çalışmaya 90 gebe dahil edildi. Preoperatif anksiyeteleri, Beck Anksiyete ölçeği ile değerlendirildi. Üç gruba ayrilan olgulara indüksiyonda; propofol 2,5mg/kg (grup P), tiyopental $5 \mathrm{mg} / \mathrm{kg}$ (grup T) ve ketamin $1 \mathrm{mg} / \mathrm{kg}$ (grup K) uyguland. Intraoperatif hemodinamik veriler, izole önkol (IÖK) yanıtları kaydedildi. Postoperatif dönemde Sayısal Ağrı Skoru (NRS), ilk analjezik yapılma zamanı ve Modifiye Brice Skalası (MBS) ile farkındalıkları değerlendirildi.

Bulgular: Grupların preoperatif anksiyete seviyeleri düşük, demografik verileri benzerdi $(p>0,05)$. IÖK yanıtlarında istatistiksel fark yoktu $(p>0,05)$. Grup T'de tüm zamanlardaki ortalama arter basıncı ve 0 . saatteki NRS değerleri diğer gruplardan yüksek $(p<0,05)$, ilk analjezik yapılma zamanı daha erkendi $(p<0,05)$. MBS yanıtları incelendiğinde; grup $K^{\prime}$ de 12, grup P'de dört, grup T'de üç olguda hatırlama olduğu belirlendi.

Sonuç: Gebelerdeki anksiyete düzeyleri düşüktü. Indüksiyonda kullanılan ajanların her birinin farkındalık üzerinde üstünlüğü gösterilememiştir.

Anahtar Sözcükler: Anksiyete, bispektral indeks, sezaryen seksiyo, end-tidal sevofluran, farkındalık, izole önkol
Address for Correspondence/Yazışma Adresi: Gamze Küçükosman

Bülent Ecevit University Faculty of Medicine, Department of Anesthesiology and Reanimation, Zonguldak, Turkey E-mail: gamzebeu@gmail.com ORCID ID: orcid.org/0000-0001-5224-0258

Received/Geliş Tarihi: 05 June 2018 Accepted/Kabul Tarihi: 23 July 2018
${ }^{\circ}$ Copyright 2019 by The Medical Bulletin of istanbul Haseki Training and Research Hospital The Medical Bulletin of Haseki published by Galenos Yayınevi. ${ }^{8}$ Telif Hakkı 2019 istanbul Haseki Eğitim ve Araştırma Hastanesi Haseki Tıp Bülteni, Galenos Yayınevi tarafından yayınlanmıştır. 


\section{Introduction}

In the preoperative period, $60-80 \%$ of patients undergoing surgery experience anxiety, known to negatively affect surgery, anesthesia and recovery (1$3)$. The incidence of anxiety in the obstetric population is $73.3-86 \%(2,4,5)$. Preoperative anxiety may lead to hypertension and dysrhythmia causing requirements for more anesthetic agents for induction, thus, increasing the risk of intraoperative awareness (IOA) and postoperative analgesic consumption and longer length of hospital stay $(3,6-8)$.

Awareness is defined as postoperative recall of events occurring during the period of general anesthesia (GA) (8). In obstetrics, the incidence of IOA is known to be higher compared to other surgical populations (9-10).

For cesarean section (CS) operations, GA is chosen due to reasons like the status of mother and fetus, mother's request or contraindications for neuraxial anesthesia (11). The use of low concentrations due to reasons, such as physiological changes in pregnancy, administration of rapid sequence anesthesia induction, lack of use of opioids and benzodiazepines before birth, short period between induction and the start of surgery and uterine atony caused by volatile anesthetics, are listed among factors contributing to IOA in CS (12-13).

Hemodynamic parameters and subjective clinical signs, such as movement, sweating, and tears, are routinely used to determine depth of anesthesia during GA (12). Although there is no fully sensitive and specific monitor to assess anesthesia depth, technological developments have ensured efficacy in assessing GA $(12,14)$. Bispectral index (BIS) is an electroencephalogram method of producing a numerical value from 0 to 100 to specifically, practically and continuously measure the effects of hypnosis caused by administration of anesthetic and sedative medications on the brain. Thus, the medication dose may be set and appropriate anesthesia depth may be ensured without increasing the IOA risk $(9,14)$. For surgeries like CS with IOA risk, a BIS score of $<60$ has been reported to be sufficient as a target value (12-16).

The isolated forearm (IFA) technique was first used by Tunstall (17) to identify IOA during CS.

Although minimum alveolar concentration (MAC) is known to be lower in pregnant women, electroencephalographic analysis studies have determined no difference $(15,16,18,19)$.

As depth of anesthesia in pregnant women may be low during the first stages of laryngoscopy, intubation and surgery, exaggerated hemodynamic responses and awareness are commonly observed in these periods. Anesthesia induction and maintenance are important in pregnant women considering transmission of medications through the placenta and effects on the baby. In our study, the aim was to research the effects of preoperative anxiety and different GA administration on IOA in elective CS cases.

\section{Methods}

Our study began after receiving permission from Bülent Ecevit University Faculty of Medicine Clinical Research Ethics Committee (meeting protocol no: 2013-59-24/04, date: 31.07.2013) and informed consent was obtained from the pregnant women. The study was performed in a prospective randomized manner from August 2013 to August 2014. The study included 90 patients aged 18-45 years, in the American Society of Anesthesiologists (ASA) risk groups I-II, who were scheduled for elective CS and refused spinal anesthesia. Exclusion criteria were history of late intubation, psychiatric or neurologic disorder, preterm pregnancies, diabetes mellitus, hypertension and obstetric complications.

All patients had the Beck Anxiety Inventory (BAI) applied and demographic information recorded during one-to-one interviews in the waiting room with an anesthesiologist not participating in the study. The BAI is a 21-item assessment scale with the aim of determining the incidence and severity of anxiety experienced by an individual. Each item is rated on a scale of 0 to 3 . Total score, ranging between 0 and 63 , increases with the severity of anxiety (20). Turkish validity and reliability has been determined by Ulusoy et al. (21).

The patients had standard monitoring applied in the operating room [mean arterial pressure (MAP), heart rate $(\mathrm{HR})$, and peripheral oxygen saturation $\left.\left(\mathrm{SpO}_{2}\right)\right]$. Each patient had a BIS probe placed on the forehead region. An Intravenous (IV) therapy $0.9 \mathrm{NaCl}$ infusion was started. The patients were laid in 10-15 degree left lateral position to prevent aorto-caval compression. The forearm without intravenous access and blood pressure sleeve was wrapped with cotton with pneumatic tourniquet placed for the IFA (Immunofluorescent assay) technique.

After three minutes (min) of preoxygenation, the patients randomly divided into three groups ( $n=30$ each) had induction administered IV with $2.5 \mathrm{mg} / \mathrm{kg}$ propofol (Propofol 1\%, Fresenius Kabi, Avusturia) in group P, 5 mg/ kg Na-thiopental (Pental thiopental Na flacon, Ibrahim Etem, İstanbul, Turkey) in group $\mathrm{T}$ and $1 \mathrm{mg} / \mathrm{kg}$ ketamine (Ketamine HCL, Eczacıbaşı, Kırklareli, Turkey) in group $K$. For the IFA technique, the pneumatic tourniquet was inflated to $250 \mathrm{mmHg}$ and isolation of the arm was ensured. Then, $1.5 \mathrm{mg} / \mathrm{kg}$ succinylcholine (Lysthenon, Linz Pharmaceuticals, Austria) IV was administered and intubation was completed. For anesthesia maintenance, all groups had $4 \mathrm{~L} / \mathrm{min} 50 / 50 \% \quad \mathrm{O}_{2} /$ air and $2 \%$ 
sevoflurane. After intubation, end-tidal carbon dioxide pressure and end-tidal sevoflurane (Etsev) concentration were monitored. After delivery, all patients had $1 \mathrm{mcg} / \mathrm{kg}$ fentanyl IV and 20 units of oxytocin infusion administered. After the peritoneum was closed, all cases had $1 \mathrm{mg} /$ kg IV tramadol administered. Sevoflurane was stopped on the start of subcutaneous suturing. The IFA test was completed at intubation (T1), skin incision (SI, T2), 1 min after intubation (AI, T3), at uterine incision (UI, T4) and at birth of the baby (T5). For the test, the patients were asked to squeeze the researcher's hand every $2 \mathrm{~min}$ and responses were recorded as positive $(+)$ if hand squeezing occurred and negative (-) if did not occur. After the baby was born, the tourniquet was loosened.

For $\mathrm{HR}, \mathrm{MAP}, \mathrm{SpO}_{2}$, BIS and Etsev, values were recorded as baseline values before induction (T0) and at T1, T2, T3, T4, T5, 5 min Al (T6), 7 min Al (T7) and while completing subdermal (T8) and skin suturing (T9). The duration of anesthesia, surgery, extubation, and recovery were recorded. Additionally, the induction-birth interval (ID) and uterine incision-birth interval were recorded. The 1 and 5 minute APGAR scores of newborns and postoperative nausea-vomiting of the mothers were recorded.

The pain Numerical Rating Scale (NRS), on which patients rate their current pain intensity from 0 ("no pain") to 10 ("worst possible pain"), has become the most widely used instrument for pain screening. Although it was not developed or validated as a screening test, the NRS is ubiquitous as a screening method in many health care environments (22). The patients had NRS values recorded in the postoperative 0,1 and 3 hours and time to first analgesic recorded. All cases had awareness assessed as responses to the following questions on the Modified Brice Scale (MBS) in the postoperative $1^{\text {st }}$ and $3^{\text {rd }}$ hours and $1^{\text {st }}$ and $3^{\text {rd }}$ days: 1 - What was the last thing you recalled before losing consciousness? 2- What was the first thing you recalled when waking? 3-Do you recall anything from the period between losing consciousness and waking? 4- Did you dream during the procedure? 5Did you hear any sounds or music during the operation? (23). Interviews recorded statements of patients about dreaming intraoperatively or hearing sounds.

\section{Statistical Analysis}

Statistical analysis in the study was completed using the SPSS 24.0 software. When assessing the study data, descriptive statistical methods (frequency, mean, standard deviation) were used in addition to the KolmogorovSmirnov test to investigate normal distribution. Comparison between the 3 groups of variables with normal distribution used the one way analysis of variance (ANOVA). Quantitative variables without normal distribution had the Mann-Whitney $U$ test applied for statistical assessment. The Pearson chi-square test and Fisher's exact test were used for comparison of qualitative data. The results were assessed in the $95 \%$ confidence interval with the level of significance $p<0.05$.

\section{Results}

A total of 90 pregnant women were included in the study. There was no statistical difference between the groups in terms of demographic data, ASA risks, BAI values, anesthesia, surgery, extubation and recovery durations ( $p>0.05$; Table 1). There was no significant difference in mean HR value between the groups, except at T4 measurement time ( $p>0.05$; Table 2 ). In terms of MAP values between the groups, there was a significant difference identified $(p<0.05)$, apart from at T8 and T9 measurement times. After induction, the increase in blood pressure was observed to be greater in group $\mathrm{T}$ (Table 3 ). Apart from the baseline BIS values $(p=0.229)$, there were significant differences identified in BIS values measured

\begin{tabular}{|c|c|c|c|c|}
\hline & $\begin{array}{l}\text { Group P } \\
(n=30)\end{array}$ & $\begin{array}{l}\text { Group T } \\
(n=30)\end{array}$ & $\begin{array}{l}\text { Group K } \\
(n=30)\end{array}$ & $p$ \\
\hline Age (year) & $29.13 \pm 4.95$ & $29.40 \pm 5.91$ & $28.60 \pm 4.37$ & 0.827 \\
\hline Weight (kg) & $77.40 \pm 15.34$ & $76.53 \pm 14.10$ & $75.37 \pm 12.09$ & 0.831 \\
\hline Height $(\mathrm{cm})$ & $162.17 \pm 5.53$ & $162.90 \pm 4.94$ & $160.53 \pm 6.50$ & 0.730 \\
\hline Body mass index $\left(\mathrm{kg} / \mathrm{m}^{2}\right)$ & $29.35 \pm 5.20$ & $28.71 \pm 4.70$ & $29.11 \pm 4.34$ & 0.869 \\
\hline ASA (I/II) (n) & $10 / 20$ & $16 / 14$ & $16 / 14$ & 0.195 \\
\hline BAI & $7.36 \pm 4.50$ & $7.46 \pm 3.66$ & $7.26 \pm 4.28$ & 0.983 \\
\hline Anesthesia duration (min) & $36.20 \pm 11.56$ & $35.83 \pm 16.60$ & $40.10 \pm 17.69$ & 0.501 \\
\hline Surgery duration (min) & $36.37 \pm 11.62$ & $37.60 \pm 16.16$ & $40.90 \pm 17.44$ & 0.497 \\
\hline Extubation duration (sec) & $270.50 \pm 12.80$ & $286.50 \pm 97.95$ & $287.00 \pm 94.43$ & 0.788 \\
\hline Recovery duration (sec) & $439.33 \pm 147.10$ & $477.33 \pm 111.41$ & $505.67 \pm 129.34$ & 0.147 \\
\hline
\end{tabular}


at all times. After intubation, the BIS values in group $\mathrm{K}$ were identified to be always higher compared to the other two groups ( $p<0.001$; Table 4$)$. From intubation to birth, there was no significant difference in IFA responses identified between the groups ( $p>0.05$; Table 5). There was no significant difference in the mean Etsev at all times between the groups ( $p>0.05$; Figure 1). When all groups were assessed together, in the duration from intubation to birth, there was no statistically significant difference identified between IFA responses, Etsev and BIS values for the group means ( $p>0.05$; Table 6$)$. At T3, the mean Etsev (0.642) in patients without IFA response was found to be higher than the mean Etsev (0.489) in patients with IFA response $(p=0.008)$. There was a statistically significant difference between the groups in terms of pain scores at postoperative hour $0(p=0.003)$ and the time to first analgesic requirement $(p<0.001$; Table 7$)$. There was no difference between the groups in terms of APGAR scores, nausea-vomiting, ephedrine, atropine and additional muscle relaxant administration and operation durations ( $p>0.05)$.

During interviews in the postoperative $1^{\text {st }}$ and $3^{\text {rd }}$ hours and $1^{\text {st }}$ and $3^{\text {rd }}$ days, in the $1^{\text {st }} h, 1$ patient in group $P$ reported dreaming, while by the $3^{\text {rd }}$ day the number of patients reporting dreaming increased to 2 . In group $\mathrm{K}$, in the $1^{\text {st }} \mathrm{h}, 6$ patients reported dreaming, while by the $3^{\text {rd }}$ day, this number had risen to 10 . In group $T$, at all interviews, 1 patient reported dreaming. Again in group $K$, in the $1^{\text {st }}$ hour, 1 patient and by the $3^{\text {rd }}$ day 3 people reported hearing voices and music during the operation, while 1 and 2 patients reported hearing voices and music in group P and group $T$, respectively; and this number did not increase.

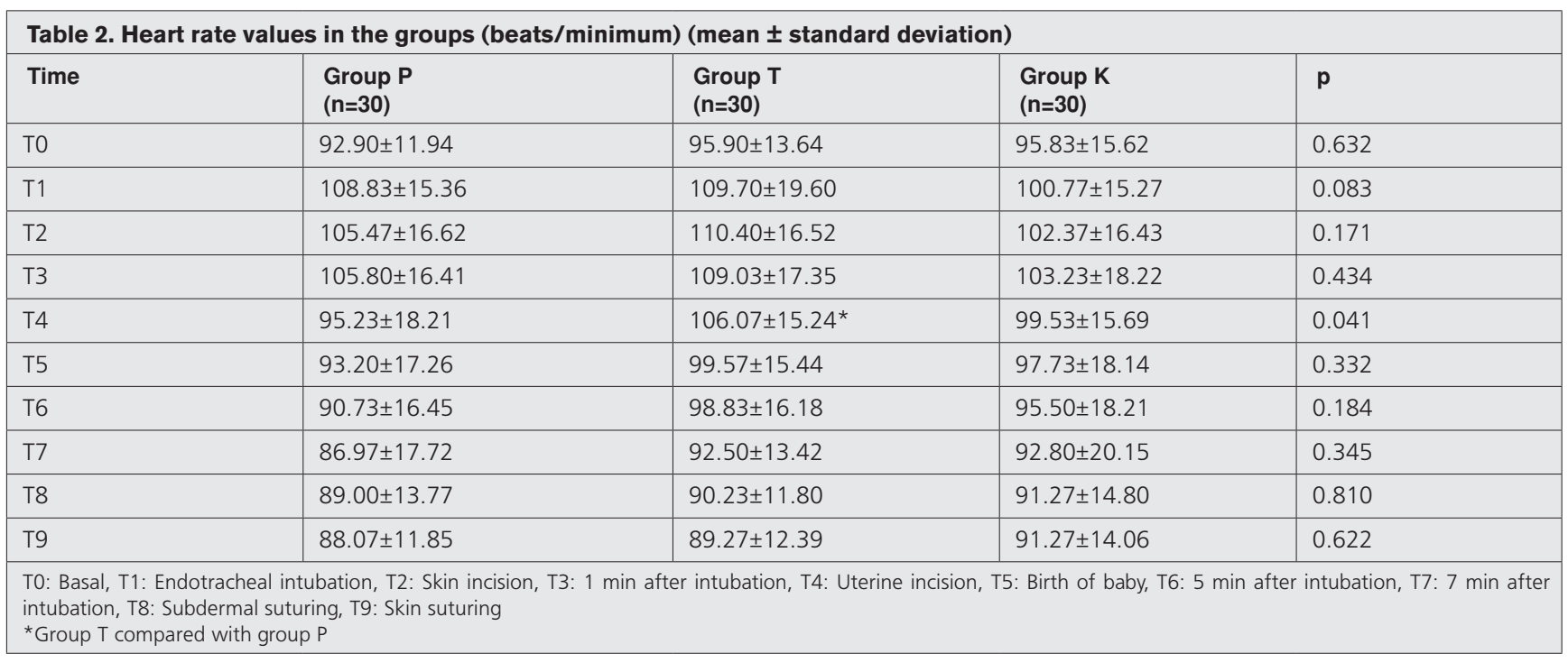

\begin{tabular}{|c|c|c|c|c|}
\hline Time & $\begin{array}{l}\text { Group P } \\
(n=30)\end{array}$ & $\begin{array}{l}\text { Group T } \\
(n=30)\end{array}$ & $\begin{array}{l}\text { Group K } \\
(n=30)\end{array}$ & p \\
\hline TO & $102.83 \pm 14.45$ & $108.07 \pm 17.21$ * & $97.20 \pm 15.41$ & 0.032 \\
\hline T1 & $111.90 \pm 17.21$ & $133.87 \pm 18.71^{\text {** }}$ & $117.03 \pm 21.34$ & 0.000 \\
\hline $\mathrm{T} 2$ & $111.53 \pm 16.21$ & $129.33 \pm 18.64^{\star *}$ & $114.00 \pm 16.84$ & 0.000 \\
\hline T3 & $111.03 \pm 16.19$ & $129.10 \pm 25.10 \varpi$ & $116.13 \pm 20.10$ & 0.004 \\
\hline T4 & $99.93 \pm 12.44$ & $117.13 \pm 19.78^{* *}$ & $104.50 \pm 15.37$ & 0.000 \\
\hline T5 & $94.77 \pm 16.08$ & $120.07 \pm 18.51^{\text {** }}$ & $102.03 \pm 15.58$ & 0.000 \\
\hline T6 & $93.70 \pm 21.94$ & $111.33 \pm 20.62^{\sigma}$ & $97.10 \pm 13.29$ & 0.001 \\
\hline $\mathrm{T7}$ & $82.20 \pm 15.08$ & $97.37 \pm 16.67^{\sigma}$ & $90.63 \pm 12.17$ & 0.001 \\
\hline T8 & $82.47 \pm 14.71$ & $91.67 \pm 14.37^{\sigma}$ & $85.97 \pm 9.89$ & 0.028 \\
\hline T9 & $88.67 \pm 13.53$ & $94.83 \pm 11.66$ & $89.10 \pm 11.95$ & 0.106 \\
\hline
\end{tabular}




\begin{tabular}{|c|c|c|c|c|}
\hline Time & $\begin{array}{l}\text { Group P } \\
(n=30)\end{array}$ & $\begin{array}{l}\text { Group T } \\
(n=30)\end{array}$ & $\begin{array}{l}\text { Group K } \\
(n=30)\end{array}$ & $p$ \\
\hline TO & $96.57 \pm 3.29$ & $97.50 \pm 0.68$ & $97.20 \pm 1.51$ & 0.229 \\
\hline T1 & $44.70 \pm 7.75$ & $49.07 \pm 9.42$ & $89.97 \pm 6.17^{*}$ & $<0.001$ \\
\hline $\mathrm{T} 2$ & $44.03 \pm 9.56$ & $55.90 \pm 10.80^{\varpi}$ & $88.70 \pm 6.87^{*}$ & $<0.001$ \\
\hline T3 & $44.50 \pm 10.23$ & $55.63 \pm 11.66^{\sigma}$ & $86.13 \pm 16.35^{*}$ & $<0.001$ \\
\hline T4 & $45.33 \pm 10.92$ & $58.43 \pm 10.18^{\sigma}$ & $83.67 \pm 9.17^{*}$ & $<0.001$ \\
\hline T5 & $44.37 \pm 11.44$ & $62.77 \pm 7.29^{\varpi}$ & $80.47 \pm 11.06^{*}$ & $<0.001$ \\
\hline T6 & $47.20 \pm 9.94$ & $61.27 \pm 9.45^{\varpi}$ & $73.40 \pm 11.45^{*}$ & $<0.001$ \\
\hline $\mathrm{T7}$ & $49.60 \pm 9.58$ & $60.57 \pm 9.15^{\sigma}$ & $68.87 \pm 13.10 *$ & $<0.001$ \\
\hline T8 & $50.57 \pm 9.90$ & $52.43 \pm 10.94$ & $61.40 \pm 7.53^{*}$ & $<0.001$ \\
\hline T9 & $51.47 \pm 9.93$ & $53.10 \pm 9.64$ & $61.40 \pm 7.75^{*}$ & $<0.001$ \\
\hline
\end{tabular}

T0: Basal, T1: Endotracheal intubation, T2: Skin incision, T3: 1 min after intubation, T4: Uterine incision, T5: Birth of baby, T6: 5 min after intubation, T7: 7 min after intubation, T8: Subdermal suturing, T9: Skin suturing,

*Group K compared with group P and group T, "'Group T compared with group P

\begin{tabular}{|l|l|l|l|l|}
\hline \multicolumn{5}{|c|}{ Table 5. Isolated forearm test responses in the groups } \\
\hline Time & $\begin{array}{l}\text { Group } \mathbf{P} \\
(\mathbf{n},+/-)\end{array}$ & $\begin{array}{l}\text { Group T } \\
(\mathbf{n},+/-)\end{array}$ & $\begin{array}{l}\text { Group K } \\
(\mathbf{n},+/-)\end{array}$ & $\mathbf{p}$ \\
\hline T1 & $2 / 28$ & $4 / 26$ & $1 / 29$ & 0.338 \\
\hline T2 & $3 / 27$ & $5 / 25$ & $1 / 29$ & 0.201 \\
\hline T3 & $3 / 27$ & $5 / 25$ & $1 / 29$ & 0.201 \\
\hline T4 & $3 / 27$ & $3 / 27$ & $1 / 29$ & 0.492 \\
\hline T5 & $2 / 28$ & $2 / 28$ & $1 / 29$ & 0.794 \\
\hline
\end{tabular}

$\mathrm{n}$ : Number of cases, +: Positive response, -: Negative response; T1: Endotracheal intubation, T2: Skin incision, T3: 1 min after intubation, T4: Uterine incision, T5: Birth of baby

\section{ETSEVO}

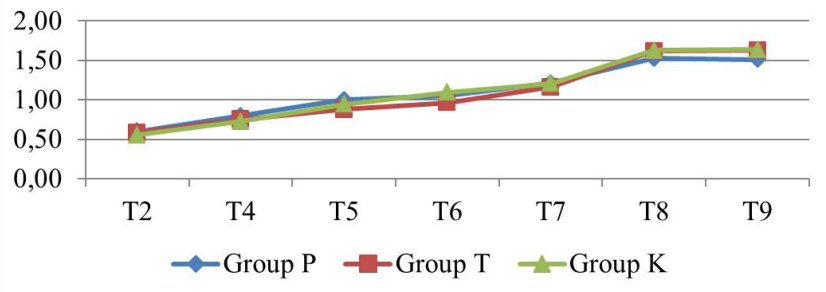

Figure 1. End-tidal Sevoflurane values in groups $P_{1} T$ and $K$. T2: Skin incision, T4: Uterine incision, T5: Birth of baby, T6: 5 min after intubation, T7: 7 min after intubation, T8: Subdermal suturing T9: Skin suturing

\begin{tabular}{|c|c|c|c|c|c|}
\hline Time & $\begin{array}{l}\text { IFA } \\
(n,+/-)\end{array}$ & Etsev & BIS & p1 & p2 \\
\hline T1 & $7 / 83$ & $50.85 \pm 21.60 / 62.12 \pm 21.86$ & - & 0.165 & - \\
\hline $\mathrm{T} 2$ & $9 / 81$ & $0.47 \pm 0.10 / 0.59 \pm 0.16$ & $61.44 \pm 19.03 / 63.03 \pm 21.39$ & 0.824 & 0.606 \\
\hline T3 & $9 / 81$ & $0.48 \pm 0.10 / 0.64 \pm 0.17$ & $63.33 \pm 18.77 / 61.95 \pm 22.30$ & 0.819 & 0.008 \\
\hline T4 & $7 / 83$ & $0.72 \pm 0.17 / 0.76 \pm 0.23$ & $65.28 \pm 18.20 / 62.24 \pm 19.01$ & 0.712 & 0.732 \\
\hline T5 & $5 / 85$ & $0.94 \pm 0.23 / 0.94 \pm 0.23$ & $70.60 \pm 20.40 / 63.11 \pm 16.68$ & 0.286 & 0.796 \\
\hline
\end{tabular}

IFA: Isolated forearm response (+: Positive response, -: Negative response), n: Number of cases; Etsev: End tidal sevoflurane concentration; BIS: Bispectral index; T1: Endotracheal intubation, T2: Skin incision, T3: 1 minute after intubation, T4: Uterine incision, T5: Birth of baby; p1=IFA compared with BIS, p2=IFA compared with Etsev

\begin{tabular}{|l|l|l|l|l|}
\hline \multicolumn{7}{|l|}{ Table 7. Numerical rating scale and duration to first analgesic (mean \pm standard deviation) } \\
\hline Time & Group $\mathbf{P}(\mathbf{n}=\mathbf{3 0})$ & Group $\mathbf{T}(\mathbf{n}=\mathbf{3 0})$ & Group K $(\mathbf{n}=\mathbf{3 0})$ & $\mathbf{p}$ \\
\hline 0. NRS (h) & $1.97 \pm 2.14$ & $2.93 \pm 2.31^{*}$ & $1.00 \pm 1.14$ & 0.003 \\
\hline 1. NRS (h) & $2.10 \pm 1.34$ & $2.17 \pm 0.87$ & $1.90 \pm 1.15$ & 0.446 \\
\hline 3. NRS (h) & $0.77 \pm 0.72$ & $0.93 \pm 0.82$ & $0.83 \pm 0.69$ & 0.734 \\
\hline First analgesic time (min) & $33.17 \pm 29.60$ & $20.33 \pm 18.79 *$ & $40.50 \pm 27.86$ & $<0.001$ \\
\hline Group P: Propofol, Group T: Thiopental, Group K: Ketamine; NRS: Numerical rating scale; $h$ : Hour, min: Minute, * Group T compared to group K \\
\hline
\end{tabular}




\section{Discussion}

In our study, as the preoperative anxiety levels in all groups were low, the effect of anxiety on IOA could not be determined. In cases with response to IFA test in the $1^{\text {st }}$ minute after intubation, especially, the Etsev values were low and we did not identify a difference in BIS values between patients who responded to the IFA test and those who did not. For identification of awareness in the period from induction to birth, BIS, Etsev, IFA responses and postoperative MBS interviews were not sufficient and we believe it is appropriate to perform interviews in the late postoperative period. Ketamine may increase awareness, while thiopental may prevent perception of awareness by increasing analgesia requirements due to not having analgesic properties, and propofol causes less awareness and thus, we believe that it is an appropriate choice for CS.

Patients' fears of anesthesia and surgery, death and pain as well as fears about the health of the infant may result in anxiety and awareness (3). Though fear of birth has been stated to increase anxiety among pregnant women, there are studies reporting the contrary $(24,25)$. Time is important in preoperative anxiety measurements, however, there is no clear difference reported between levels of anxiety assessed at different times $(3,8,14)$. In our study, we believe that the pregnant women had low anxiety levels because they were informed at the previous visit and demographic data were similar.

As clinical signs, such as elevated blood pressure and pulse rate, are regulated by the autonomous system, they may be affected by other factors (hypervolemia, hypoxia, hypercapnia, pain, beta blocker use) apart from IOA $(12,26,27)$. In pregnant women, the hypotensive effect is observed more commonly with propofol induction and there are worries about ensuring sufficient anesthesia depth (12). However, propofol dose of $2.5 \mathrm{mg} / \mathrm{kg}$ is sufficient to prevent awareness, has the advantage of reducing maternal blood pressure for hypertensive patients and is reported to reduce the cardiovascular response to laryngoscopy and intubation (28). Similarly, it has been reported that medications with different doses and combinations may be used for CS $(29,30)$. In our study, we believe that the reason for the clear increases in MAP and HR in group T compared to the other groups was the fact that thiopental suppresses catecholamine release less and has no analgesic effect.

To identify awareness, methods like BIS monitoring, end tidal agent concentration, MBS interviews and IFA techniques are recommended (12,13,31-33). Although the use of BIS monitoring has been reported to reduce the incidence of awareness, there are studies reporting the contrary $(9,13,14,18,34,35)$. In our study, especially after intubation, there were higher BIS values (61-89) in group $\mathrm{K}$ compared to the other two groups and according to BIS, we can say that anesthesia depth was appropriate for all patients apart from group K. Due to the very short duration until birth in CS, we believe that the induction agent still affects BIS values until birth.

It has been reported that BIS monitoring may be helpful in determining the volatile anesthetic concentration required to ensure sufficient anesthesia depth in the duration until the fetus in born in CS $(8,9,13-16,31)$. Chin and Yeo (15) stated that there was a risk of high awareness in the period before delivery in CS and that Etsev should be at least 1.2-1.3\% to obtain a BIS value of $<60$ for this period. The use of subanesthetic doses of sevoflurane in the preoxygenation period in pregnant women has been said to reduce the time to reach the targeted end-tidal concentration and aid in setting BIS $<60$ (32). Ok et al. (18) stated that 1.0\% Etsev did not provide $\mathrm{BIS}<60$ until birth; thus, higher Etsev or IV administration of anesthetics or opioids after birth might be better. Zand et al. (31) recommended that volatile anesthetic concentration above $1 \mathrm{MAC}$ not be used in CS due to the properties of fetal depression and dose-linked myometrial relaxation. Mashour et al. (34) stated that BIS observation might be better in preventing awareness compared to monitoring end tidal agent concentration. In our study, in all groups with 1 MAC sevoflurane, chosen due to low blood/gas coefficient, $1.2 \%$ Etsev was reached only in the $7^{\text {th }}$ minute and in groups $\mathrm{P}$ and $\mathrm{T}$ we identified that, BIS was $<60$ with Etsev $\geq 1.2 \%$.

Studies comparing BIS with IFA technique have not observed hand movements with BIS<60 without laryngoscopy, intubation or painful stimuli, however, in the presence of a strong painful stimulus even at $\mathrm{BIS}<50$, patient's response to commands was not prevented. As a result, it was stated that BIS monitoring was insufficient to determine IFA response $(31,36)$. There is a very low rate of correlation reported between intraoperative response assessed with BIS and the IFA technique (37). A study by Jeon et al. (38) using the IFA technique reported that there was no awareness between skin incision with BIS $<75$ and immediately after birth with BIS<85. In our study, there was no difference between the groups in terms of IFA response, with the least number of positive responses obtained from group K. In the presence of painful stimuli, responses are obtained from the IFA test independent of $\mathrm{BIS}$, and we believe that the analgesic effect of ketamine may be effective in preventing this response and the initial low Etsev may cause positive responses to the IFA test.

Ketamine at subanesthetic doses has been reported to reduce postoperative pain levels and 24-hour analgesic requirements among CS patients $(28-30,39)$. In our study, 
we observed that the time to first analgesic requirement was longer and the postoperative analgesic consumption was lower in group $\mathrm{K}$. We believe that administration of ketamine before nociceptive stimulation ensured preemptive analgesia.

Together with the consideration that dreaming or possible awareness is a result of superficial anesthesia, there is a very weak relationship between dreaming during anesthesia and depth of anesthesia $(8,40)$. Wanna et al. $(41)$ observed no awareness among pregnant women with propofol and ketamine induction, with a very low number of patients dreaming in both groups, no difference between the groups and stated that propofol and ketamine might be safely used for pregnant women. In the postoperative recovery room, patients may be groggy and feel a continuous desire to sleep so they may roughly explain their experience, without stating details. In the early postoperative period, pain and nausea-vomiting may prevent recollection of intraoperative experiences (42). As the first postoperative interview to determine awareness may not be reliable, it is recommended that this type of evaluation be performed two or three times at different times $(13,16,18,29,31,34,35)$. We found that the highest number of patients who dreamed was in group K. Additionally, we identified that 1 patient in group P, 1 patient in group $T$ and four patients in group $\mathrm{K}$ heard noise and music during the operation. In group T, 1 patient heard the commands given in the IFA assessment, did not dream and heard a baby crying during the operation. We believe that repeated interviews in the postoperative $1^{\text {st }}$ week or in the later periods will increase the reported incidence of awareness.

\section{Study Limitations}

The first is that as ASA I-II pregnant patients were included, we cannot know whether the results can be generalized, especially among high-risk pregnancies. Second, instead of continuously assessing the IFA responses, we checked hand movements at certain time points. As a result, we did not identify awareness between these time points. Third, we did not use a peripheral nerve stimulator to ensure no tourniquet paralysis of the hand. Though there is a very low possibility of this occurring, unexpected paralysis of the same hand may be responsible for cases not responding in spite of high BIS values.

\section{Conclusion}

IOA is a significant complication of GA. In our study, since the preoperative anxiety levels in patients undergoing CS were low, we could not assess their effect on awareness. We believe that the available GA and monitoring methods are insufficient to assess the depth of anesthesia. Ketamine causes more dreaming and hearing of sounds during the operation compared to other anesthetics and we believe that this may cause problems in terms of awareness. Due to its antianalgesic properties, thiopental increases analgesic requirements in the early postoperative period and we assume that this may have prevented recall of experiences and thus identification of awareness. Propofol lowered BIS values, caused less IFA response compared to thiopental and caused less awareness when the MBS results were examined. As a result, we point out that the use of propofol for anesthesia induction is appropriate for CS.

\section{Authorship Contributions}

Surgical and Medical Practices: N.N.G., G.K., B.G.A., M.i.H., H.A. Concept: N.N.G., G.K., B.G.A., M.i.H., H.A. Design: N.N.G., G.K., B.G.A., M.I.H., H.A. Data Collection or Processing: N.N.G., G.K., B.G.A., D.R.O., Ö.P., Ü.S. Analysis or Interpretation: N.N.G., G.K., B.G.A., D.R.O., Ö.P. Literature Search: N.N.G., G.K., Writing: N.N.G., G.K., B.G.A., H.A.

Conflict of Interest: No conflict of interest was declared by the authors.

Financial Disclosure: The authors declared that this study received no financial support.

\section{References}

1. Norris W, Baird WL. Pre-operative anxiety: a study of the incidence and aetiology. Br J Anaesth 1967;39:503-9.

2. Shevde K, Panagopoulos G. A survey of 800 patients' knowledge, attitudes, and concerns regarding anesthesia. Anesth Analg 1991;73:190-8.

3. Badner NH, Nielson WR, Munk S, Kwiatkowska C, Gelb AW. Preoperative anxiety: detection and contributing factors. Can J Anaesth 1990;37:444-7.

4. Vallejo MC, Phelps AL, Shepherd CJ, Kaul B, Mandell GL, Ramanathan S. Nitrous oxide anxiolysis for elective cesarean section. J Clin Anesth 2005;17:543-8.

5. Wyatt SS, Jones DA, Peach MJ, Gurrin L. Anxiety in patients having caesarean section under regional anaesthesia: a questionnaire and pilot study. Int J Obstet Anesth 2001;10:278-83.

6. Goldmann L, Ogg TW, Levey AB. Hypnosis and daycase anaesthesia. A study to reduce pre-operative anxiety and intra-operative anaesthetic requirements. Anaesthesia 1988;43:466-9.

7. Ip HY, Abrishami A, Peng PW, Wong J, Chung F. Predictors of postoperative pain and analgesic consumption: a qualitative systematic review. Anesthesiology 2009;111:657-77.

8. Sandin RH, Enlund G, Samuelsson P, Lennmarken C. Awareness during anaesthesia: a prospective case study. Lancet 2000;355:707-11.

9. Paech MJ, Scott KL, Clavisi O, Chua S, McDonnell N; ANZCA Trials Group. A prospective study of awareness and recall associated with general anesthesia for Cesarean section. Int J Obstet Anesth 2008;17:298-303.

10. Bischoff P, Rundshagen I. Awareness under general anesthesia. Dtsch Arztebl Int 2011;108:1-7. 
11. Birnbach DJ, Browne IM. Miller's Anesthesia. 10th ed. Vol. 69. Philadelphia: Elsevier; 2010. Anesthesia for obstetrics; p. 2219.

12. Robins K, Lyons G. Intraoperative awareness during general anesthesia for cesarean delivery. Anesth Analg 2009;109:886-90.

13. Hadavi SM, Allahyary E, Asadi S. Evaluation of the adequacy of general anesthesia in cesarean section by bispectral index. Iran J Med Sci 2013;38:240-7.

14. Myles PS, Leslie K, McNeil J, Forbes A, Chan MT. Bispectral index monitoring to prevent awareness during anaesthesia: the B-Aware randomised controlled trial. Lancet 2004;363:1757-63.

15. Chin KJ, Yeo SW. A BIS-guided study of sevoflurane requirements for adequate depth of anesthesia in Cesarean section. Anesthesia 2004;59:1064-8.

16. Choi WJ, Kim SH, Koh WU, et al. Effect of pre-exposure to sevoflurane on the bispectral index in women undergoing Cesarean delivery under general anesthesia. $\mathrm{Br} J$ Anesth 2012;108:990-7.

17. Tunstall ME. Detecting wakefulness during general anaesthesia for caesarean section. Br Med J 1977;21:1321.

18. OK SJ, Kim WY, Lee YS, et al. The effects of midazolam on the bispectral index after fetal explusion in Cesarean section under general anesthesia with sevoflurane. J Int Med Res 2009;37:154-62

19. Ueyama H, Hagihira S, Takashina M, Nakae A, Mashimo T. Pregnancy does not enhance volatile anesthetic sensitivity on the brain: an electroencephalographic analysis study. Anesthesiology 2010;113:577-84.

20. Beck AT, Epstein N, Brown G, Steer RA. An inventory for measuring clinical anxiety: psychometric properties. J Consult Clin Psychol 1988;56:893-7.

21. Ulusoy $M$, Şahin $N$, Erkmen $H$. Turkish version of Beck Anxiety inventory: Psychometric properties. Journal of Cognitive Psychotherapy: An international Cjuaterly 1998;12:163-72.

22. Krebs EE, Carey TS, Weinberger M. Accuracy of the Pain Numeric Rating Scale as a Screening Test in Primary Care. Gen Intern Med 2007;22:1453-8.

23. Brice DD, Hetherington RR, Utting JE. A simple study of awareness and dreaming during anaesthesia. $\mathrm{Br} J$ Anaesth 1970;42:535-42.

24. Hobson JA, Slade P, Wrench IJ, Power L. Preoperative anxiety and postoperative satisfaction in women undergoing elective caesarean section. Int J Obstet Anesth 2006;15:18-23.

25. Blüml V, Stammler-Safar M, Reitinger AK, Resch I, Naderer A, Leithner K. A qualitative approach to examine women's experience of planned cesarean. J Obstet Gynecol Neonatal Nurs 2012;41:82-90.

26. von Dincklage F, Send K, Hackbarth M, Rehberg B, Baars JH. Comparison of the nociceptive flexion reflex threshold and the bispectral index as monitors of movement responses to noxious stimuli under propofol mono-anaesthesia. $\mathrm{Br} J$ Anaesth 2009;102:244-50.

27. Sanders RD, Tononi G, Laureys S, Sleigh JW. Unresponsiveness $\neq$ unconsciousness. Anesthesiology 2012;116:946-59.
28. Murdoch $\mathrm{H}$, Scrutton $\mathrm{M}$, Laxton $\mathrm{CH}$. Choice of anaesthetic agents for caesarean section: A UK survey of current practice. Int J Obstet Anesth 2013;22:31-5.

29. Nayar R, Sahajanand $H$. Does anesthetic induction for Cesarean section with a combination of ketamine and thiopentone confer any benefits over thiopentone or ketamine alone? A prospective randomized study. Minerva Anestesiol 2009;75:185-90.

30. Rajan S, Hassain A, Puthenveettil N, Kumar L. Efficacy and safety of low-dose ketamine as an adjunct analgesic and amnesic during caesarean section under general anaesthesia. Indian J Anaesth 2015;59:653-7.

31. Zand F, Hadavi SM, Chohedri A, Sabetian P. Survey on the adequacy of depth of anaesthesia with bispectral index and isolated forearm technique in elective Caesarean section under general anaesthesia with sevoflurane. $\mathrm{Br} J$ Anaesth 2014;112:871-8.

32. Chin KJ, Yeo SW. Bispectral index values at sevoflurane concentrations of $1 \%$ and $1.5 \%$ in lower segment cesarean delivery. Anesth Analg 2004;98:1140-4.

33. Stein EJ, Glick DB. Advances in awareness monitoring technologies. Curr Opin Anaesthesiol 2016;29:711-6.

34. Mashour GA, Shanks A, Tremper KK, et al. Prevention of intraoperative awareness with explicit recall in an unselected surgical population. A randomized comparative effectiveness trial. Anesthesiology 2012;117:717-25.

35. Avidan MS, Jacobsohn E, Glick D, et al. Prevention of intraoperative awareness in a high-risk surgical population. $\mathrm{N}$ Engl J Med 2011;365:591-600.

36. Flaishon R, Windsor A, Sigl J, Sebel PS. Recovery of consciousness after thiopental or propofol. Bispectral index and isolated forerm technique. Anesthesiology 1997;86:6139.

37. Russell IF.The ability of bispectral index to detect intraoperative wakefulness during isoflurane/air anaesthesia, compared with the isolated forearm technique. Anaesthesia 2013;68:1010-20.

38. Jeon SY, Lim HJ, Cho $\mathrm{H}$, et al. Awareness detection during a cesarean section under general anesthesia using bispectral index monitoring. Korean J Anesthesiol 2000;39:632-63.

39. Reza FM, Zahra F, Esmaeel F, Hossein A. Preemptive analgesic effect of ketamine in patients undergoing elective cesarean section. Clin J Pain 2010;26:223-226.

40. Leslie K, Skrzypek H, Paech MJ, Kurowski I, Whybrow T. Dreaming during anesthesia and anesthetic depth in elective surgery patients: a prospective cohort study. Anesthesiology 2007; 106:33-42.

41. Wanna O, Werawatganon T, Piriyakitphaiboon S, Taesiri B. A comparison of propofol and ketamine as induction agents for cesarean section. J Med Assoc Thai 2004;87:774-9.

42. Ghoneim MM, Block RI, Haffarnan M, Mathews MJ. Awareness during anesthesia: risk factors, causes and sequelae: a review of reported cases in the literature. Anesthesia Analgesia 2009;108:527-35. 